\title{
EFFECT OF BUILDING FORM WITH INNER COURT AND HEIGHT VARIATIONS ON THERMAL COMFORT OUTDOOR SPACE IN SUDIRMAN SUITES APARTMENT BANDUNG
}

\author{
${ }^{1}$ Natalia Hamdani. ${ }^{2}$ Nancy Yusnita Nugroho, S.T., M.T. \\ ${ }^{1}$ Student in the Bachelor's (S-1) Study Program in Architecture \\ at Parahyangan Catholic University \\ ${ }^{2}$ Senior lecturer in the Bachelor's (S-1) Study Program in Architecture \\ at Parahyangan Catholic University
}

\begin{abstract}
Designing apartment as a vertical residence should not only pay attention to aesthetics value but also aspects comfort aspects, such as thermal comfort. Apartment thermal comfort is not only limited to indoor units but also outdoor space as residents' communal area. Sudirman Suites Apartment built in the center of Bandung City with limited land availability is selected as the research object because of the uniqueness of the building form with inner court and height variation that allows the availability of outdoor space on the floor above.

Sudirman Suite Apartments' building form and height can affect the site's microclimate and outdoor space thermal comfort. This study aims to determine the effect of building form with inner court and height variation to thermal comfort of apartment outdoor space as well as the right solution to improve it.

This study used quantitative method, with descriptive evaluative type of research. Measurements were taken on the Sudirman Suite Apartment outdoor space such as ground floor parking area, terrace, and aisle, 1st floor inner court, 2nd floor roof garden, and sky garden on 9th and 11th floor. The measurement data then calculated into thermal comfort perception and analyzed based on theories of literature study result to reach conclusion.

Influence of the building form and height to outdoor space thermal comfort the thermal comfort of Sudirman Suites Apartment analysis divided into: outdoor space on the main mass with inner court and height variations, pilotis on the ground floor of the main mass, and supporting mass addition. Besides of the building form and height, environmental factors also affect the outdoor space thermal comfort such as wind and radiative temperatures in each outdoor space.

Based on this study, it is known that there is significant effect of the apartment's form with inner court, where the comparison between blocking tower height and comparable distance between towers makes inner court area air flow tend to be low. Pilotis on the ground floor increases the speed of air flow on the ground floor. Sun radiation reduction occurs in the sky garden area overshadowed by building form with height variation. Outdoor space elements optimization is considered less optimal in supporting thermal comfort, such as the lack of plants and rooftop surface area dominated by hardscape.
\end{abstract}

Key Words: apartment, outdoor space, thermal comfort, Bandung Sudirman Suites

\section{PENGARUH BENTUK BANGUNAN DENGAN INNER COURT DAN VARIASI KETINGGIAN TERHADAP KENYAMANAN TERMAL RUANG LUAR DI APARTEMEN SUDIRMAN SUITES BANDUNG}

\author{
${ }^{1}$ Natalia Hamdani. ${ }^{2}$ Nancy Yusnita Nugroho, S.T., M.T. \\ ${ }^{1}$ Mahasiswi S1 Program Studi Arsitektur Universitas Katolik Parahyangan \\ ${ }^{2}$ Dosen Pembimbing S1 Program Studi Arsitektur Universitas Katolik Parahyangan
}

\begin{abstract}
Abstrak- Perancangan apartemen sebagai sebuah hunian vertikal sebaiknya tidak hanya memperhatikan nilai estetis tetapi juga aspek kenyamanan, salah satunya kenyamanan termal. Kenyamanan termal apartemen tidak sebatas ruang dalam unit hunian tetapi juga ruang luar sebagai area komunal penghuni. Apartemen Sudirman Suites yang dibangun di pusat KotaBandung dengan lahan terbatas dijadikan objek penelitian karena keunikan bentuk bangunan dengan inner court dan variasi ketinggian yang memungkinkan adanya ruang luar di lantai atas.
\end{abstract}

\footnotetext{
${ }^{1}$ Corresponding Author: nataliahamdani11@gmail.com
} 
Bentuk dan ketinggian Apartemen Sudirman Suite dapat memengaruhi iklim mikro tapak serta kenyamanan termal ruang luar. Penelitian ini bertujuan untuk mengetahui pengaruh bentuk bangunan dengan inner court dan variasi ketinggian terhadap kenyamanan termal ruang luar apartemen serta solusi yang tepat dalam upaya meningkatkannya.

Metode yang digunakan adalah metode kuantitatif, dengan jenis penelitian deskriptif evaluatif. Pengukuran dilakukan pada ruang luar Apartemen Sudirman Suite seperti area parkir, teras, dan lorong lantai dasar, inner court lantai 1, roof garden lantai 2, serta sky garden lantai 9 dan 11. Hasil data pengukuran kemudian dihitung persepsi kenyamanan termalnya dan dianalisis berdasarkan teori hasil studi literatur untuk mencapai kesimpulan.

Pembahasan pengaruh bentuk dan ketinggian bangunan terhadap kenyamanan termal ruang luar Apartemen Sudirman Suites dibagi menjadi: ruang luar pada massa utama dengan inner court dan variasi ketinggian, pilotis pada lantai dasar massa utama, dan adisi massa penunjang. Selain pengaruh bentuk dan ketinggian bangunan, faktor lingkungan pun berpengaruh bagi kenyamanan termal ruang luar seperti hembusan angin dan suhu radiatif pada setiap ruang luarnya.

Berdasarkan penelitian yang dilakukan, diketahui bahwa ada pengaruh yang signifikan dari bentuk bangunan dengan inner court, di mana perbandingan antara ketinggian tower penghalang dengan jarak antar tower yang hampir sebanding membuat aliran udara pada area inner court cenderung rendah. Pilotis pada lantai dasar mengakibatkan kecepatan aliran udara pada lantai dasar meningkat. Reduksi radiasi matahari terjadi pada area sky garden yang terbayangi akibat bentuk massa yang memiliki variasi ketinggian. Optimasi elemen ruang luar dinilai kurang dalam menunjang kenyamanan termal, seperti minimnya tanaman dan permukaan area rooftop yang didominasi perkerasan.

Kata Kunci: apartemen, ruang luar, kenyamanan termal, Sudirman Suites Bandung

\section{PENDAHULUAN}

Dalam rangka memenuhi kebutuhan akan tempat tinggal ditengah keterbatasan lahan, apartemen sebagai sebuah hunian vertikal merupakan salah satu solusi yang semakin marak dilakukan khususnya di kota-kota besar. Selain memperhatikan nilai estetika, aspek kenyamanan seperti kenyamanan termal pada unit hunian ataupun ruang luar sebagai area komunal penghuni sebaiknya diperhatikan dalam perancangan apartemen.

Apartemen Sudirman Suites merupakan apartemen yang dibangun di pusat Kota Bandung dengan keterbatasan lahan. Oleh karena itu, ruang luar tidak hanya berada di lantai dasar namun juga di lantai atas yang didukung oleh bentuk apartemen dengan inner court dan variasi ketinggian.

Bentuk dan ketinggian Apartemen Sudirman Suite dapat mempengaruhi iklim mikro tapak serta kenyamanan termal ruang luar. Jarak dan perbedaan ketinggian antara massa bangunan yang menghadap arah datangnya angin akan mempengaruhi pergerakan angin, ataupun suhu udara yang relatif tinggi saat siang hari. Dari fenomena di atas, dapat dirumuskan masalah penelitian bahwa perlu diteliti pengaruh bentuk dan ketinggian apartemen terhadap kenyamanan termal ruang luar, dengan pertanyaan penelitian (1) Apa pengaruh bentuk bangunan dengan inner court dan variasi ketinggian terhadap kenyamanan termal ruang luar Apartemen Sudirman Suites? (2) Bagaimana solusi yang tepat dalam upaya meningkatkan kenyamanan termal ruang luar Apartemen Sudirman Suites?

Penelitian ini bertujuan untuk mengetahui pengaruh bentuk bangunan dengan inner court dan variasi ketinggian terhadap kenyamanan termal ruang luar apartemen serta solusi yang tepat dalam upaya meningkatkannya. Manfaat dari penelitian ini adalah (1) menjadi sebuah evaluasi mengenai kondisi kenyamanan termal ruang luar bangunan tinggi, (2) menjadi sebuah masukan dalam meningkatkan kondisi kenyamanan termal ruang luar bangunan tinggi, (3) memberikan kontribusi bagi penelitian sejenis.

Penelitian menggunakan metode kuantitatif dengan membandingkan data hasil pengukuran yang diperoleh melalui proses survey dengan teori-teori terkait pengaruh bentuk dan ketinggian bangunan terhadap kondisi kenyamanan termal. Sampel penelitian ini yaitu beberapa titik pada area ruang luar di Aparemen Sudirman Suites seperti: area parkir, teras, koridor, inner court, roof garden, dan sky garden. Penelitian dilakukan 3 kali yaitu pada tanggal 24 Februari 2018, 21 Maret 2018, dan 7 April 2018 untuk memperoleh data terbaik. 
Setiap hari pengukuran dilakukan 3 kali yaitu pada pagi, siang, dan sore hari mempertimbangkan pengaruh sinar matahari timur dan barat terhadap kenyamanan termal yang akan diteliti.

\section{KAJIAN TEORI}

Apartemen adalah tempat tinggal yang terdiri atas banyak keluarga dan beberapa unit hunian yang saling berbagi akses yang sama dan dilingkupi oleh struktur kulit bangunan yang sama $^{2}$. Bentuk apartemen the courtyard menyediakan sisi ruang terbuka (courtyard), ketika keempat sisi ruang terbuka tertutup, maka akan menjadi sebuah inner court, yang dapat dimanfaatkan sebagai ruang terbuka yang bersifat komunal.

Ruang luar adalah Ruang luar adalah ruang yang terbentuk dengan membatasi alam dengan dua elemen pembatas yaitu lantai dan dinding, sedangkan atapnya dapat dikatakan tidak terbatas ${ }^{3}$. Secara umum aspek pembentuk ruang luar terdiri dari topografi (landform), tanaman, dan bangunan ${ }^{4}$. Aspek bangunan merupakan unsur perancangan fisik utama dari ruang luar.

Kenyamanan termal merupakan kondisi dimana ada kepuasan terhadap keadaan termal lingkungan sekitar. Kenyamanan dirasakan tubuh apabila terjadi keseimbangan termal yaitu panas yang dihasilkan tubuh setara dengan pelepasan dan perolehan panas tubuh ${ }^{5}$. Kondisi kenyamanan termal dipengaruhi oleh faktor iklim (lingkungan) dan faktor individu (personal). Faktor lingkungan terdiri atas: suhu udara, kelembapan udara, kecepatan udara dan radiasi termal. Faktor lingkungan bersifat fluktuatif sepanjang waktu karena kondisi cuaca berubah-ubah serta berbeda pada setiap daerahnya. Sedangkan faktor personal terdiri atas: jenis aktivitas yang dilakukan serta jenis pakaian yang digunakan. Semakin berat kerja tubuh maka tubuh semakin menghasilkan panas. Selain itu, makin tebal pakaian maka panas tubuh pun semakin sulit dilepas.

Manusia cenderung bersifat lebih toleran dalam merespon iklim di ruang luar terhadap tingkat kenyamanannya dibanding ketika berada di ruang dalam, sehingga memerlukan indeks yang berbeda dengan indeks kenyamanan termal ruang dalam. Untuk mengetahui tingkat kenyamanan termal ruang luar pada iklim tropis lembab, Sangkertadi membagi formulasi regresi atas dua kasus aktivitas yaitu jalan santai dan duduk santai ${ }^{6}$.

Persamaan untuk aktifitas manusia berjalan santai berpakaian tropis:

$$
\mathrm{YJS}=-3.4-0,36 \mathrm{AV}+0.04 \mathrm{t} \mathrm{a}+0.08 \mathrm{tg}-0.01 \mathrm{RH}+0.96 \mathrm{Adu}
$$

Persamaan untuk aktifitas manusia duduk santai berpakaian tropis:

$$
\mathrm{YD}=-7.91-0.52 \mathrm{AV}+0.047 \mathrm{ta}+0.167 \mathrm{tg}-0.0007 \mathrm{RH}+1.43 \mathrm{Adu}
$$

Keterangan :

YJS = Persepsi Kenyamanan termis (jalan santai)

YD = Persepsi Kenyamanan termis (duduk)

$\mathrm{AV}=$ Kecepatan Angin menyentuh tubuh $(\mathrm{m} / \mathrm{s})$

ta $=$ Suhu Udara $\left({ }^{\circ} \mathrm{C}\right)$

$\operatorname{tg} \quad=$ Suhu Radiasi $\left({ }^{\circ} \mathrm{C}\right)$

$\mathrm{RH}=$ Kelembaban Relatif $(\%)$

$\mathrm{Adu}=$ Luas Kulit Tubuh $\left(\mathrm{m}^{2}\right)$

\footnotetext{
${ }^{2}$ DE Chiara, Joseph \& John Callender. 1987. Time Saver Standards For Building Types: 2nd edition. Singapura: McGraw-Hill Book.

3 PRABAWASARI, V. W. \& Suparman, A. 1999. Tata Ruang Luar 01. Jakarta: Penerbit Gunadarma.

${ }^{4}$ BOOTH, Norman K. 1983. Basic Elements of Landscape Architectural Design. Illinois: Waveland Press.

${ }^{5}$ ASHRAE. 1989. "Handbook of Fundamental Chapter 8" Physiological Principles, Comfort, and Health. USA: ASHRAE.

${ }^{6}$ SANGKERTADI. 2013. Kenyamanan Termis di Ruang Luar Beriklim Tropis Lembab. Bandung: Alfabeta.
} 
Nilai Adu (luar kulit tubuh manusia) yang digunakan yaitu sebesar $1,8 \mathrm{~m}^{2}$. Hal ini berdasarkan formula Du Bois yang merupakan korelasi eksponensial dari faktor berat dan tinggi badan rata-rata manusia dewasa dengan tinggi badan $165 \mathrm{~cm}$ dan berat badan $70 \mathrm{~kg}$ yang berpakaian tropis santai.

Hasil pengukuran lapangan selanjutnya dihitung sesuai dengan formulasi perhitungan kenyamanan termal, untuk mendapatkan skala kenyamanan pada masing-masing titik pengukuran. Kemudian hasil perhitungan dibandingkan dengan tabel skala kenyamanan termal untuk mengetahui bagaimana persepsi kenyamanan termal suatu ruang luar.

Tabel 1. Skala Kenyamanan Termal

\begin{tabular}{|c|c|}
\hline Nilai Y & Persepsi \\
\hline-1 & Agak Dingin \\
\hline 0 & Nyaman \\
\hline 1 & Agak Panas \\
\hline 2 & Panas \\
\hline 3 & Sangat Panas \\
\hline 4 & Sangat Panas dan Rasa Sakit \\
\hline
\end{tabular}

Gerakan udara terjadi disebabkan oleh pemanasan lapisan-lapisan udara yang berbeda-beda. Udara bergerak dari daerah dengan suhu yang lebih rendah dengan tekanan lebih tinggi (positif) ke daerah dengan suhu yang lebih tinggi dengan tekanan lebih rendah (negatif) ${ }^{7}$.

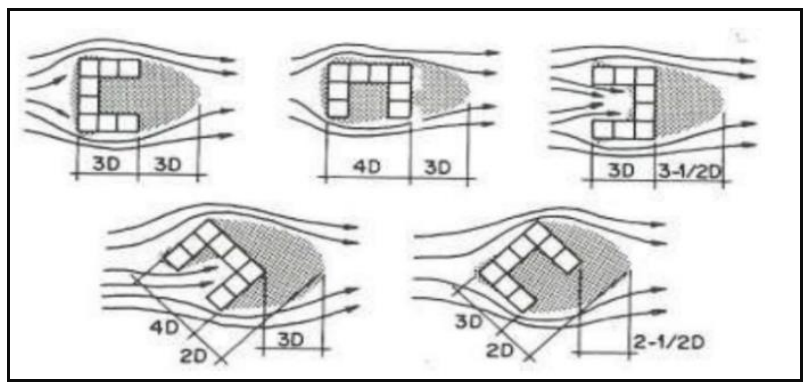

Figur 1. Pengaruh Orientasi Bentuk Bangunan U Terhadap Gerakan Angin

Bangunan berbentuk $U$ menciptakan ukuran area tenang yang relatif sama namun efektivitas aliran udara pada masing-masing orientasi berbeda. Seperti pada gambar di atas, ketika bangunan berbentuk U membelakangi arah datangnya angin, pola aliran udara pada bangunan mirip seperti pada bangunan persegi. Sebaliknya ketika bangunan berbentuk U menghadap arah datangnya angin, aliran udara menuju bentuk $U$ pada bangunan dan meningkatkan kecepatan angin dalam bangunan. Selain itu, orientasi bangunan yang berbeda terhadap datangnya angin turut menciptakan area terlindung yang berbeda ${ }^{8}$.

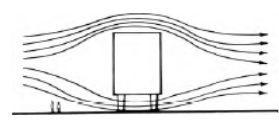

Figur 2. Bangunan Tinggi dengan Pilotis

\footnotetext{
${ }^{7}$ MANGUNWIJAYA, Y.B. 1988. Pengantar Fisika Bangunan, Jakarta: Djambatan.

8 BOUTET, Terry S. 1987. Controlling Air Movement. New York: R. R. Doneley \& Sons Company.
} 
Bangunan tinggi yang bagian dasarnya diangkat (pilotis) sehingga terbentuk kolong di bagian bawah bangunan, cenderung mengalami kecepatan angin yang sangat tinggi pada lantai dasar karena udara dapat mengalir melalui kolong bangunan tersebut.

Bangunan tinggi terkena aliran angin lebih kuat akibat tinggi badannya dan dapat menimbulkan pola aliran udara turbulen ke bawah menuju level dasar bangunan tinggi, yang dikenal dengan downwash effect. Aspek rasio jarak antara bangunan dan tinggi bangunan memiliki peran mendasar terhadap efek downwash. Efek yang terjadi akan berbeda ketika parameter $\mathrm{H}$ (tinggi bangunan) dan $\mathrm{W}$ (jarak antar bangunan) berbeda. Semakin tinggi gedung penghalang maka kecepatan aliran semakin menurun. Semakin jauh jarak gedung penghalang terhadap gedung bertingkat maka kecepatan aliran udara akan meningkat ${ }^{9}$.

Selain itu, bentuk dan proporsi bangunan turut mempengaruhi radiasi yang terjadi. Seperti pada bentuk bangunan dengan inner court, dimensi dan proporsi luasan inner court mempengaruhi yakni, semakin luas bukaan inner court, maka semakin luas bidang yang terkena radiasi matahari, dan semakin tinggi bangunan maka semakin luas daerah yang terkena pembayangan.

Selain massa bangunan, terdapat faktor lain yang mempengaruhi gerakan udara ataupun radiasi yaitu elemen lansekap. Elemen lansekap dapat mengarahkan dan mengurangi ataupun meningkatkan kecepatan gerakan udara di sekitar tapak dan bangunan. Di samping itu, elemen lansekap juga dapat digunakan sebagai pelindung terhadap radiasi matahari dengan memberikan pembayangan yang mereduksi pemanasan permukaan bangunan dan tanah di sekitarnya.

\section{METODA PENELITIAN}

Penelitian menggunakan metode kuantitatif, di mana data hasil pengukuran kemudian dianalisis dengan cara membandingkan hasil studi lapangan dengan teori yang diperoleh dari studi literatur. Setelah proses penganalisisan dapat ditarik kesimpulan yang menjawab pertanyaan penelitian yang sebelumnya diajukan.

- Tempat dan Waktu Penelitian

Penelitian dilakukan di Apartemen Sudirman Suites yang berlokasi di Jalan Jenderal Sudirman no. 588, Kelurahan Dungus Cariang, Kecamatan Andir, Kota Bandung, Jawa Barat. Pengambilan data dilakukan dalam tiga kali dengan tiga fase waktu yang berbeda, yaitu pada pagi hari (pukul 08.00-09.00 WIB), siang hari (pukul 12.00-13.00 WIB), dan sore hari (pukul 16.00-17.00 WIB). Pengambilan data dilakukan tiga kali pada tiga bulan yang berbeda yaitu 24 Februari 2018 mempertimbangkan ramalan BMKG mengenai bulan dengan angin dan curah hujan terbesar, 21 Maret 2018 terjadi fenomena equinox, dan 7 April 2018 berlandaskan prediksi suhu terhangat Kota Bandung sepanjang tahun 2018 yang jatuh pada bulan April.

- Data Objek

Apartemen Sudirman Suites dibangun di atas lahan $7000 \mathrm{~m}^{2}$ di Kota Bandung. Pengembang apartemen ini yaitu Istana Group, dengan arsitek adalah PT. PTI Architects, dan kontraktor PT Wika Gedung, PT. Indopora. Apartemen ini terdiri dari 23 lantai dan 800 unit hunian. Apartemen Sudirman Suites terdiri atas 5 tipe unit hunian.

\footnotetext{
${ }^{9}$ OKE, T.R. 1978. Boundary Layer Climates. New York: John Wiley and Sons.
} 


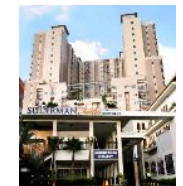

Figur 3. Apartemen Sudirman Suites

- Populasi dan Sampel

Populasi penelitian ini adalah seluruh ruang luar Apartemen Sudirman Suites. Sampel penelitian yaitu pada area sekitar bangunan (area parkir) lantai dasar, teras dan jalur sirkulasi/ lorong lantai dasar dan 1, lounge lantai 1, inner court lantai 1, roof garden lantai 2, dan sky garden lantai 9 dan 11. Ketinggian titik ukur menyesuaikan dengan kegiatan yang dominan dilakukan pada titik ukur, yang dibagi menjadi dua yaitu pada posisi duduk dan berdiri. Ketinggian posisi duduk yaitu $75 \mathrm{~cm}$ dan berdiri $120 \mathrm{~cm}$, mempertimbangkan data antropometri.

- Alat Ukur Penelitian

Alat ukur yang digunakan untuk penelitian yaitu 4 in 1 tester dan wet bulb globe temperature/ WBGT. Alat 4 in 1 tester digunakan untuk mengukur kecepatan angin. Alat wet bulb globe temperature digunakan untuk mengukur suhu udara, kelembapan udara dan suhu radiasi.

- Simulasi

Simulasi yang digunakan yaitu dengan menggunakan software Autodesk Flow Design dan SketchUp. Software Autodesk Flow Design digunakan untuk simulasi pergerakan udara disekitar bangunan. Software SketchUp digunakan untuk mengetahui bagaimana pembayangan akibat bentuk bangunan dengan inner court dan variasi ketinggian pada 3 fase waktu penelitian terhadap ruang luar sebagai upaya mengurangi radiasi.

- Teknik Analisis Data

Data pengukuran suhu udara, kelembapan relatif, suhu radiasi, dan kecepatan gerakan udara yang diperoleh dari tiga kali pengukuran disajikan dalam bentuk grafik, karena dapat memvisualkan data hasil pengukuran dari satu titik ke titik lainnya, sehingga dapat diketahui kecenderungan pola pergerakannya dan titik mana yang perbedaannya signifikan dibandingkan titik lainnya yang akan dianalisis untuk mengetahui kondisi termal hasil pengukuran secara umum.

Kemudian data pengukuran suhu udara, kelembapan relatif, suhu radiasi, dan kecepatan gerakan udara yang diperoleh dihitung berdasarkan formulasi perhitungan kenyamanan termal Sangkertadi sesuai aktivitasnya yaitu berjalan atau duduk. Nilai hasil perhitungan yang diperoleh kemudian dibandingkan dengan tabel skala kenyamanan termal Sangkertadi. Data hasil pengukuran dan hasil perhitungan (nilai Y dan persepsinya) kemudian disajikan dalam bentuk tabel dan dianalisis terkait pengaruh bentuk dan ketinggian terhadap kenyamanan termal ruang luar Apartemen Sudirman Suites. Analisis tersebut ditunjang oleh data hasil simulasi menggunakan Software Autodesk Flow Design dan Software SketchUp.

Hasil analisis akan menemukan area mana yang kondisinya di luar zona nyaman dan faktor pengaruhnya yang pembahasannya difokuskan pada kondisi kecepatan gerakan udara dan suhu radiasi. Hasil analisis kemudian ditarik kesimpulan yang akan menjawab pertanyaan penelitian mengenai bagaimana kondisi kenyamanan termal ruang luar serta sejauh apa bentuk dan ketinggian bangunan mempengaruhi kondisi kenyamanan termal ruang luar apartemen. Saran terkait hasil penelitian akan diberikan 
sebagai rekomendasi guna mendapatkan kondisi kenyaman termal ruang luar apartemen yang lebih baik.

\section{ANALISA}

4.1 PENGARUH BENTUK BANGUNAN DENGAN INNER COURT DAN VARIASI KETINGGIAN TERHADAP RUANG LUAR DI APARTEMEN SUDIRMAN SUITES BANDUNG

Data yang dianalisis merupakan rata-rata dari data pengukuran 2 (21 Maret 2018) dan 3 (7 April 2018) dengan pertimbangan cuaca (cerah berawan) dan pola data hasil pengukuran yang cenderung serupa, sedangkan pada data pengukuran pertama (24 Februari 2018) terdapat kendala yaitu cuaca yang kurang mendukung (mendung di sore hari) sehingga mempengaruhi data yang diperoleh. Untuk memperjelas pembahasan terkait data hasil pengukuran, berikut ini dilampirkan foto \& key plan letak titik ukur ruang luar Apartemen Sudirman Suites:

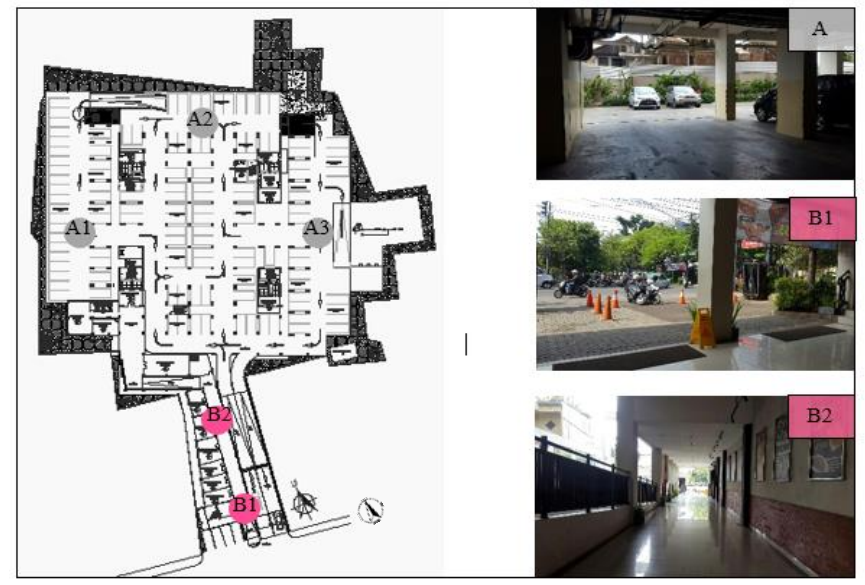

Figur 4. Area Ruang Luar Lantai Dasar

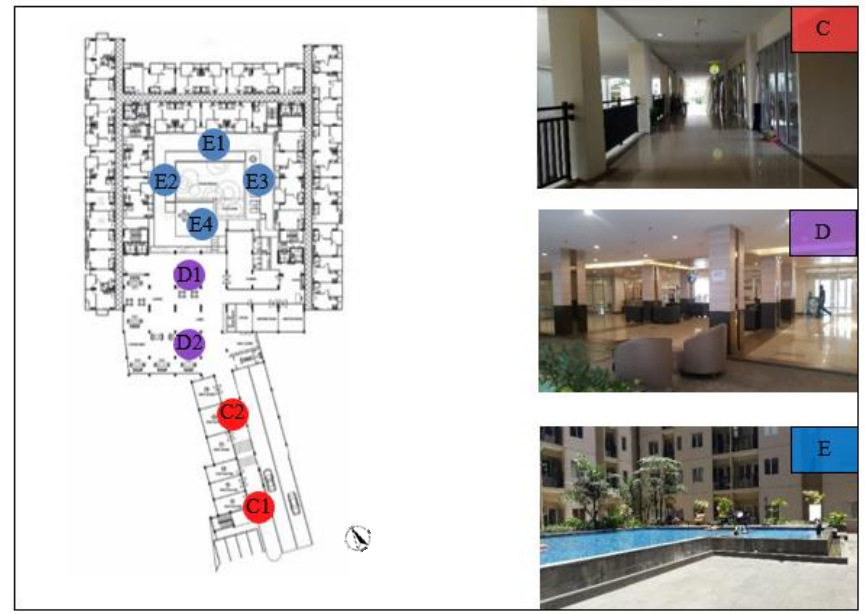

Figur 5. Area Ruang Luar Lantai 1 


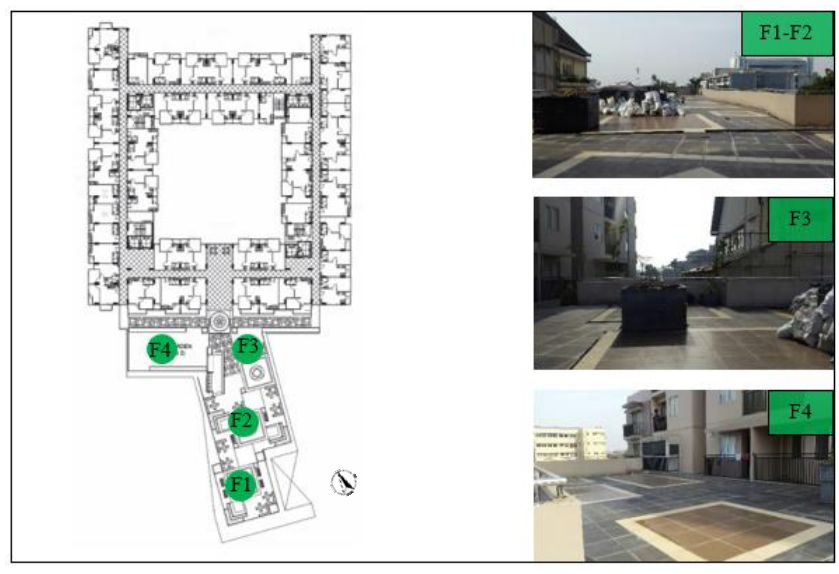

Figur 6. Area Ruang Luar Lantai 2

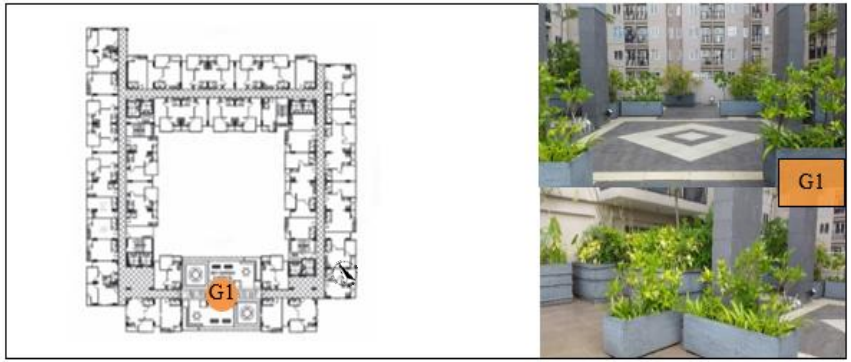

Figur 7. Area Ruang Luar Lantai 9

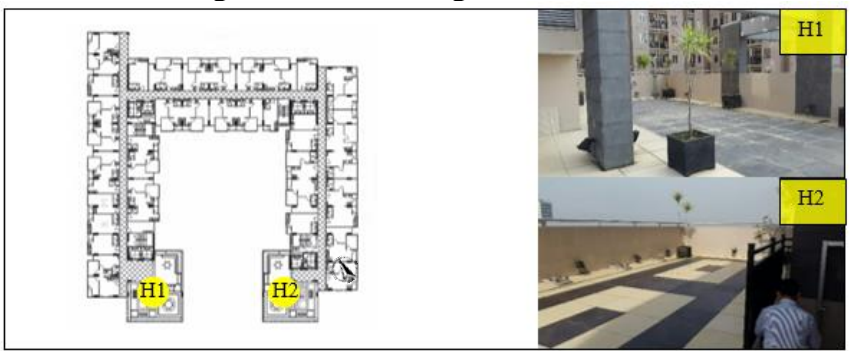

Figur 8. Area Ruang Luar Lantai 11

Dalam pembahasan pengaruh bentuk dan ketinggian bangunan terhadap kenyamanan termal ruang luar Apartemen Sudirman Suites Bandung, akan dibagi menjadi massa utama dengan inner court dan variasi ketinggian (Area D,E,G,H), pilotis pada lantai dasar massa utama (Area A), dan adisi massa penunjang (Area B, C, F).

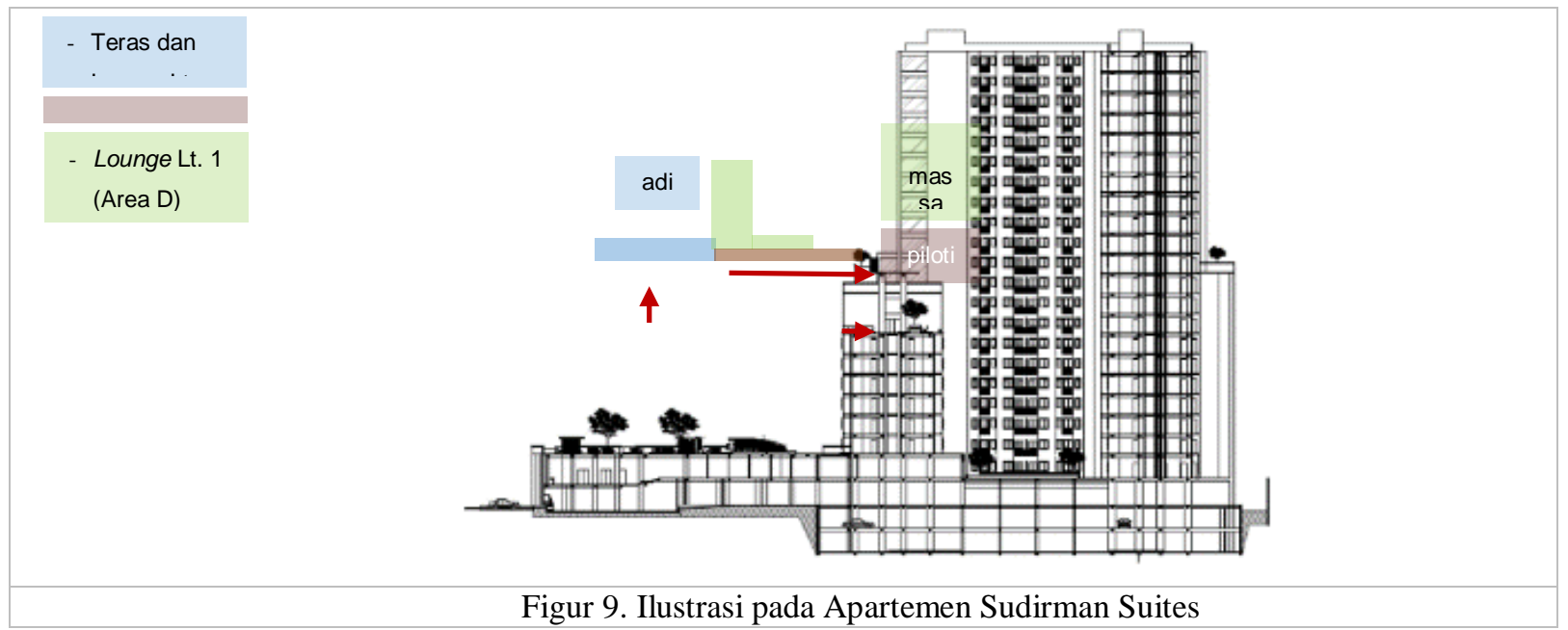




\section{a. Massa Utama dengan Inner Court dan Variasi Ketinggian}

Massa utama apartemen merupakan kesatuan 4 tower yaitu Tower Ebony setinggi 8 lantai dan Tower Mahagony, Maple, Rosewood setinggi 23 lantai dengan sebuah inner court di tengahnya. Pada massa utama terdapat 4 area yang akan dianalisis yaitu lounge lantai 1 (Area D), inner court lantai 1 (Area E), dan sky garden pada puncak Tower Mahagony dengan perbedaan ketinggian sky garden yaitu lantai 9 dan 11 (Area $\mathrm{G}$ dan $\mathrm{H}$ ).

- Lounge Lantai 1 (Area D)

Tabel 1. Persepsi Kenyamanan Termal Area Lounge Lantai 1 (Area D)

\begin{tabular}{|c|c|c|c|c|c|c|c|c|}
\hline \multirow{3}{*}{ Waktu } & \multirow{3}{*}{ TitikUkur } & \multicolumn{5}{|c|}{ Indikator } & \multirow{2}{*}{\multicolumn{2}{|c|}{ Hasil Perhitungan }} \\
\hline & & \multirow{2}{*}{$\begin{array}{l}\text { RH } \\
(\%)\end{array}$} & \multirow{2}{*}{$\frac{\operatorname{tg}}{\left({ }^{\circ} \mathrm{C}\right)}$} & \multirow{2}{*}{$\begin{array}{c}\mathrm{ta} \\
\left({ }^{\circ} \mathrm{C}\right)\end{array}$} & \multirow{2}{*}{$\begin{array}{c}\mathrm{AV} \\
(\mathrm{m} / \mathrm{s})\end{array}$} & \multirow{2}{*}{$\begin{array}{l}\text { Arah } \\
\text { Angin }\end{array}$} & & \\
\hline & & & & & & & Nilai & Persepsi \\
\hline \multirow{2}{*}{ Pagi } & D1 & 75.8 & 25.6 & 25.8 & 0.0 & $\square$ & 0.098 & Nyaman \\
\hline & D2 & 76.4 & 25.8 & 26.0 & 0.1 & $\mathrm{~S}$ & 0.089 & Nyaman \\
\hline \multirow{2}{*}{ Siang } & D1 & 68.1 & 28.9 & 28.1 & 0.7 & $\mathrm{TL}$ & 0.399 & Nyaman \\
\hline & D2 & 68.3 & 28.7 & 28.1 & 1.0 & $\mathrm{~S}$ & 0.209 & Nyaman \\
\hline \multirow{2}{*}{ Sore } & D1 & 71.0 & 26.7 & 26.6 & 0.1 & $\mathrm{TL}$ & 0.271 & Nyaman \\
\hline & D2 & 70.7 & 26.6 & 26.7 & 0.1 & TL & 0.259 & Nyaman \\
\hline
\end{tabular}

Berdasarkan hasil perhitungan pengukuran Area D (area lounge lantai 1) yang terlindungi dari sinar radiasi secara langsung pada seluruh fase waktu menunjukkan kondisi nyaman. Suhu udara pada Area D cenderung serupa antar setiap titiknya dalam setiap fase waktu akibat area lounge tidak terkena radiasi langsung, sehingga penghuni paling nyaman beraktivitas pada area ini. Suhu udara pada pagi hari sekitar $26^{\circ} \mathrm{C}$, siang hari sekitar $28^{\circ} \mathrm{C}$ dan sore hari sekitar $26-27^{\circ} \mathrm{C}$. Pada pagi dan sore hari minim angin sedangkan siang hari terjadi kenaikan kecepatan angin yang signifikan yakni titik D1 dari arah timur laut melalui bukaan menghadap inner court dan titik D2 dari arah selatan melalui koridor.

Suhu radiasi Area D juga cenderung serupa antar setiap titiknya dalam setiap fase waktu. Suhu radiasi titik D1 lebih tinggi dari pada titik D2 diakibatkan menerima pantulan radiasi panas dari area inner court yang menerima radiasi matahari secara langsung. Kondisi radiasi tertinggi yang terjadi pada siang hari berbanding terbalik dengan kondisi kelembapan relatif terendah pada siang hari. Area ini memiliki kelembapan yang cukup tinggi yang berkisar $70 \%$ akibat letaknya yang berdekatan dengan kolam renang pada area inner court.

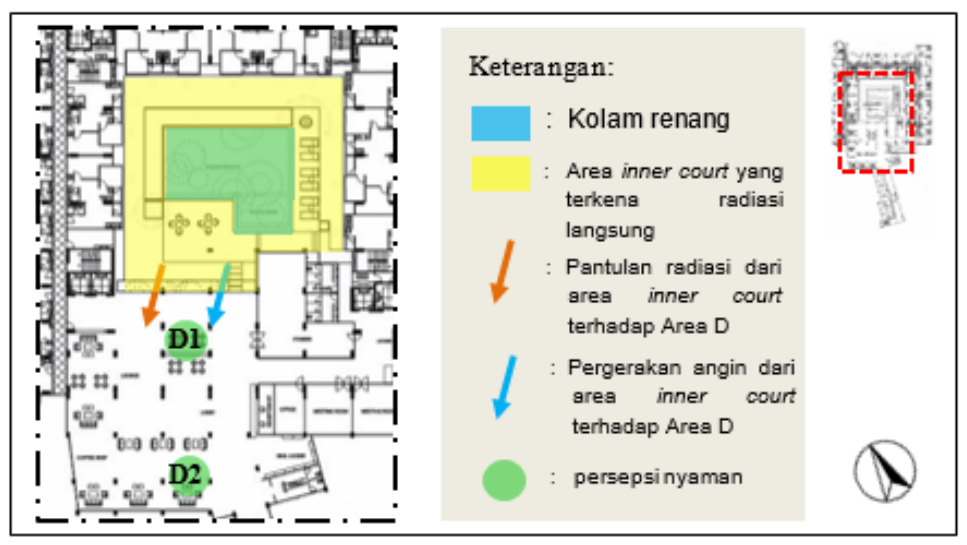

Figur 10. Ilustrasi Pengaruh Inner Court Terhadap Area D

\section{- Inner court Lantai 1 (Area E)}

Tabel 2. Persepsi Kenyamanan Termal Area Inner court Lantai 1 (Area E) 


\begin{tabular}{|c|c|c|c|c|c|c|c|c|}
\hline \multirow{3}{*}{ Waktu } & \multirow{3}{*}{ TitikUkur } & \multicolumn{5}{|c|}{ Indikator } & \multirow{2}{*}{\multicolumn{2}{|c|}{ Hasil Perhitungan }} \\
\hline & & \multirow{2}{*}{$\begin{array}{l}\mathrm{RH} \\
(\%)\end{array}$} & \multirow{2}{*}{$\begin{array}{c}\operatorname{tg} \\
\left({ }^{\circ} \mathrm{C}\right)\end{array}$} & \multirow{2}{*}{$\begin{array}{c}\text { ta } \\
\left({ }^{\circ} \mathrm{C}\right)\end{array}$} & \multirow{2}{*}{$\begin{array}{c}\mathrm{AV} \\
(\mathrm{m} / \mathrm{s})\end{array}$} & \multirow{2}{*}{$\begin{array}{l}\text { Arah } \\
\text { Angin }\end{array}$} & & \\
\hline & & & & & & & Nilai & Persepsi \\
\hline \multirow{4}{*}{ Pagi } & E1 & 74.4 & 25.9 & 25.1 & 0.3 & $\mathrm{TL}$ & 0.552 & Agak Panas \\
\hline & $\mathrm{E} 2$ & 75.4 & 25.5 & 25.2 & 0.0 & $\square$ & 0.622 & Agak Panas \\
\hline & E3 & 76.2 & 25.3 & 25.2 & 0.1 & TL & -0.031 & Nyaman \\
\hline & $\mathrm{E} 4$ & 75.9 & 25.4 & 25.1 & 0.0 & $\square$ & 0.605 & Agak Panas \\
\hline \multirow{4}{*}{ Siang } & E1 & 68.1 & 29.6 & 28.8 & 0.7 & $\mathrm{BL}$ & 0.915 & Agak Panas \\
\hline & $\mathrm{E} 2$ & 67.9 & 30.5 & 29.2 & 0.7 & TL & 1.005 & Agak Panas \\
\hline & E3 & 68.3 & 30.1 & 29.0 & 0.7 & TL & 0.641 & Agak Panas \\
\hline & E4 & 66.3 & 32.4 & 29.5 & 0.7 & $\mathrm{TL}$ & 1.185 & Agak Panas \\
\hline \multirow{4}{*}{ Sore } & E1 & 70.7 & 26.3 & 26.4 & 0.5 & $\mathrm{~T}$ & 0.601 & Agak Panas \\
\hline & $\mathrm{E} 2$ & 71.1 & 26.5 & 26.5 & 0.3 & $\mathrm{TL}$ & 0.689 & Agak Panas \\
\hline & E3 & 71.5 & 26.5 & 26.6 & 0.1 & $\square$ & 0.237 & Nyaman \\
\hline & E4 & 70.3 & 26.6 & 26.7 & 0.2 & $\mathrm{TL}$ & 0.749 & Agak Panas \\
\hline
\end{tabular}

Hasil perhitungan pengukuran Area E (area inner court) merupakan ruang terbuka memusat yang pada setiap fase waktunya memiliki persepsi yang serupa yakni titik E1, E2, E4 menunjukkan persepsi agak panas dan titik E3 menunjukkan persepsi nyaman. Hal tersebut terjadi akibat perbedaan aktivitas yaitu pada aktivitas duduk pada titik E3.

Pada pagi hari Area E minim pergerakan angin, sedangkan pada siang dan sore pergerakan udara cenderung tidak stabil diakibatkan turbulensi pada area inner court. Hal tersebut juga dipengaruhi tower yang berbentuk U setinggi 23 lantai dan keberadaan inner court di tengahnya. Sehingga angin yang masuk pada area inner court tidak sekencang bagian atas tower yang terkena hantaman angin yang kencang. Selain itu perbandingan antara ketinggian - $\mathrm{H}$ tower penghalang (8 lantai) yang lebih rendah (selisih 15 lantai) serta jarak antar massa tower - W (lebar inner court) yang tidak terlalu besar yakni nilai $\mathrm{H} / \mathrm{W}$ sekitar 1 yang hampir sebanding menimbulkan efek downwash yaitu pola aliran udara turbulen ke bawah menuju area inner court yang terjadi berupa skimming flow dengan kecepatan 0.1-0.7 m/s (cooling effect kurang terasa).

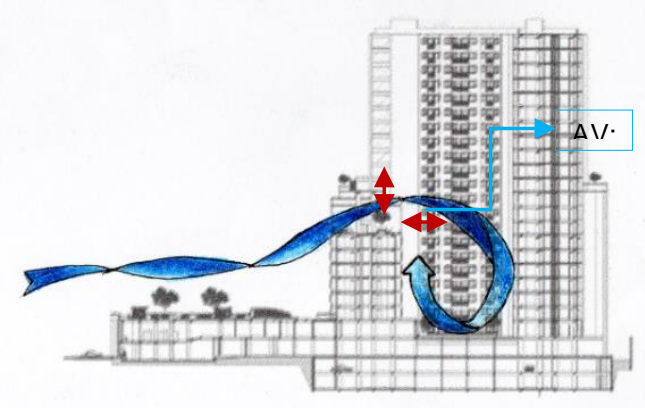

Figur 11. Ilustrasi Gerakan Udara pada Inner Court Apartemen Sudirman Suites

Massa bangunan utama yang melingkupi Area E tersebut mampu memberikan efek pembayangan penuh pada area inner court apartemen sehingga dapat mengurangi panas, yakni seluruh titik ukur pada Area E terbayangi pada pagi dan sore hari. Sehingga perbedaan suhu radiasi pada Area E di setiap titik pada pagi berkisar $25^{\circ} \mathrm{C}$ dan sore hari berkisar $26^{\circ} \mathrm{C}$ tidak terlalu berbeda namun pada siang hari yakni sebesar $30-32^{\circ} \mathrm{C}$ dengan titik ukur E1 terendah dan titik ukur E4 tertinggi dibandingkan titik ukur lainnya, sebab titik ukur E4 merupakan bidang dengan perkerasan terluas dan angin yang bertiup dari Area E ke Area D melalui titik E4 dimana ketika cuaca panas, maka panas pun akan ikut terbawa angin tersebut. Selain itu, panas akibat radiasi pada Area E menjadi lebih sulit hilang dan terperangkap sebab 
bentuk area inner court yang dikelilingi massa bangunan setinggi 8 dan 23 lantai. Sehingga radiasi dapat diserap dan saling dipantulkan pada keempat sisi Area E, selain itu gerakan udara pada area ini yang cenderung rendah juga mempengaruhi panas menjadi lebih lambat untuk hilang.

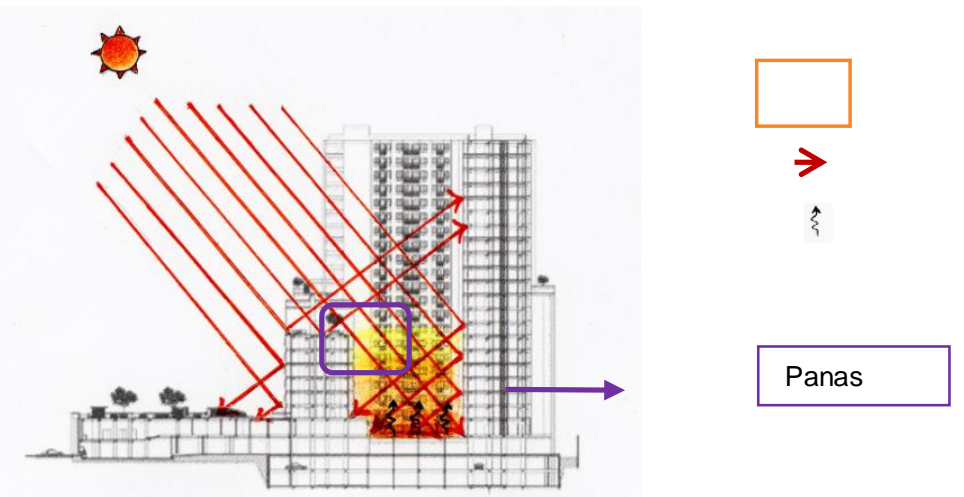

Figur 12. Ilustrasi Pantulan Radiasi pada Inner Court Apartemen Sudirman Suites

- Sky Garden Lantai 9 (Area G)

Tabel 3. Persepsi Kenyamanan Termal Area Sky Garden Lantai 9 (Area G)

\begin{tabular}{|c|c|c|c|c|c|c|c|c|}
\hline \multirow{3}{*}{ Waktu } & \multirow{3}{*}{ TitikUkur } & \multicolumn{5}{|c|}{ Indikator } & \multirow{2}{*}{\multicolumn{2}{|c|}{ Hasil Perhitungan }} \\
\hline & & \multirow{2}{*}{$\begin{array}{l}\text { RH } \\
(\%)\end{array}$} & \multirow{2}{*}{$\begin{array}{c}\operatorname{tg} \\
\left({ }^{\circ} \mathrm{C}\right)\end{array}$} & \multirow{2}{*}{$\begin{array}{c}\mathrm{ta} \\
\left({ }^{\circ} \mathrm{C}\right)\end{array}$} & \multirow{2}{*}{$\begin{array}{c}\mathrm{AV} \\
(\mathrm{m} / \mathrm{s})\end{array}$} & \multirow{2}{*}{$\begin{array}{c}\text { Arah } \\
\text { Angin }\end{array}$} & & \\
\hline & & & & & & & Nilai & Persepsi \\
\hline Pagi & G1 & 67.6 & 27.8 & 26.9 & 0.7 & $\mathrm{BD}$ & 0.700 & Agak Panas \\
\hline Siang & G1 & 58.7 & 33.0 & 31.9 & 1.6 & $\mathrm{BD}$ & 1.081 & Agak Panas \\
\hline Sore & G1 & 69.1 & 27.6 & 27.2 & 1.2 & $\mathrm{~T}$ & 0.501 & Agak Panas \\
\hline
\end{tabular}

Berdasarkan data hasil pengukuran, hasil perhitungan pengukuran Area $G$ yang merupakan sky garden lantai 9 pada setiap fase waktunya menunjukkan kondisi persepsi yang agak panas.

Pada area $\mathrm{G}$ yang merupakan sky garden lantai 9 , perbedaan suhu udara pada pagi dan sore hari tidak terlalu berbeda sekitar $26-27{ }^{\circ} \mathrm{C}$ dan pada siang hari cukup kontras perbedaannya sekitar $32{ }^{\circ} \mathrm{C}$. Kecepatan angin pada pagi hari lebih rendah sebesar $0.7 \mathrm{~m} / \mathrm{s}$ dibandingkan pada siang dan sore hari sebesar 1.6 dan $1.2 \mathrm{~m} / \mathrm{s}$, dengan arah angin dari arah barat daya dan timur yang merupakan hasil turbulensi akibat tower setinggi 23 lantai yang berbentuk U. Suhu udara dan angin yang cukup tinggi dan bertiup cukup konstan pada siang hari membuat penghuni kurang nyaman untuk beraktivitas dalam waktu yang lama pada Area G.

Pada pagi hari seluruh titik ukur G1 terbayangi oleh tower berbentuk U setinggi 23 lantai dan pada sore hari sebagian titik ukur G1 terbayangi oleh sky garden pada lantai 11, sehingga perbedaan suhu radiasi Area $G$ pada pagi dan sore hari tidak terlalu jauh yaitu berkisar $27-28^{\circ} \mathrm{C}$. Letak Area $\mathrm{G}$ yang berada ditengah dan posisinya lebih rendah dari sky garden lantai 11 cukup efektif dalam menerima pembayangan akibat variasi ketinggian. Namun pada siang hari perbedaannya menjadi kontras yaitu sebesar $33{ }^{\circ} \mathrm{C}$ akibat Area $\mathrm{G}$ tidak menerima pembayangan oleh bentuk bangunan pada siang hari, sehingga Area $G$ terkena radiasi matahari secara langsung. Tingginya suhu radiasi pada siang hari akibat Area $\mathrm{G}$ terkena radiasi matahari secara langsung, dengan keberadaan tanaman yang cukup banyak 
namun akibat jenis tanaman yang rendah (perdu dalam pot) sehingga memberikan pembayangan yang kurang luas pada Area G.

- Sky Garden Lantai 11 (Area H)

Tabel 4. Persepsi Kenyamanan Termal Area Sky Garden Lantai 11 (Area H)

\begin{tabular}{|c|c|c|c|c|c|c|c|c|}
\hline \multirow{3}{*}{ Waktu } & \multirow{3}{*}{ TitikUkur } & \multicolumn{5}{|c|}{ Indikator } & \multirow{2}{*}{\multicolumn{2}{|c|}{ Hasil Perhitungan }} \\
\hline & & \multirow{2}{*}{$\begin{array}{l}\mathrm{RH} \\
(\%)\end{array}$} & \multirow{2}{*}{$\begin{array}{c}\operatorname{tg} \\
\left({ }^{\circ} \mathrm{C}\right)\end{array}$} & \multirow{2}{*}{$\begin{array}{c}\text { ta } \\
\left({ }^{\circ} \mathrm{C}\right)\end{array}$} & \multirow{2}{*}{$\begin{array}{c}\mathrm{AV} \\
(\mathrm{m} / \mathrm{s})\end{array}$} & \multirow{2}{*}{$\begin{array}{l}\text { Arah } \\
\text { Angin }\end{array}$} & & \\
\hline & & & & & & & Nilai & Persepsi \\
\hline \multirow{2}{*}{ Pagi } & H1 & 67.0 & 28.7 & 27.6 & 0.5 & $\mathrm{BD}$ & 0.878 & Agak Panas \\
\hline & $\mathrm{H} 2$ & 66.1 & 29.8 & 28.2 & 0.7 & $\mathrm{TL}$ & 0.927 & Agak Panas \\
\hline \multirow{2}{*}{ Siang } & $\mathrm{H} 1$ & 55.6 & 35.0 & 33.0 & 2.1 & $\mathrm{BD}$ & 1.136 & Agak Panas \\
\hline & $\mathrm{H} 2$ & 55.2 & 35.5 & 33.3 & 1.6 & $\mathrm{BD}$ & 1.372 & Agak Panas \\
\hline \multirow{2}{*}{ Sore } & H1 & 69.9 & 27.2 & 26.6 & 1.9 & $\mathrm{BD}$ & 0.185 & Nyaman \\
\hline & $\mathrm{H} 2$ & 70.1 & 27.3 & 26.9 & 1.6 & $\mathrm{BD}$ & 0.311 & Nyaman \\
\hline
\end{tabular}

Dari data hasil pengukuran di atas, hasil perhitungan pengukuran Area $\mathrm{H}$ yang merupakan sky garden lantai 11 pada seluruh fase waktu dominan menunjukkan kondisi agak panas, kecuali pada sore hari kedua titik menunjukkan kondisi nyaman, hal tersebut diakibatkan oleh kecepatan angin cukup tinggi dengan suhu dan radiasi tidak setinggi siang hari.

Area $\mathrm{H}$ terletak di lantai 11 dan saling berseberangan dengan Area $\mathrm{G}$ di lantai 9 yang terletak diantaranya memiliki suhu udara pada pagi dan sore hari tidak terlalu berbeda sekitar $27-28{ }^{\circ} \mathrm{C}$ dan pada siang hari cukup kontras perbedaannya sekitar $35^{\circ} \mathrm{C}$. Kecepatan angin Area $\mathrm{H}$ ini mirip dengan Area $\mathrm{G}$, yaitu tertinggi pada siang hari dan terendah pada pagi hari dengan perbedaan kecepatan angin antar setiap area tidak menunjukan perbedaan yang signifikan. Perbedaan kecepatan angin yang tidak terlalu besar diakibatkan dengan lokasi ketinggian 30-35m, hambatan yang dijumpai sedikit akibat area sekitar apartemen merupakan bangunan rendah (1-3 lantai), selain itu selisih 2 lantai pada ketinggian ini tidak akan memberikan perbedaan kecepatan angin yang besar.

Selain kecepatan angin, arah angin pada Area $\mathrm{G}$ dan $\mathrm{H}$ menunjukkan hasil yang tidak berbeda jauh yaitu arah angin dominan berasal dari arah barat daya dan terkadang dari arah timur dan timur laut yang merupakan hasil turbulensi akibat tower berbentuk U setinggi 23 . Kesamaan tersebut terjadi akibat lokasi Area $\mathrm{G}$ dan $\mathrm{H}$ yang keduanya berada pada lantai 9 dan 11 Tower Mahagony yang berada di depan Tower Mahagony, Maple, Rosewood berbentuk U setinggi 23 lantai.
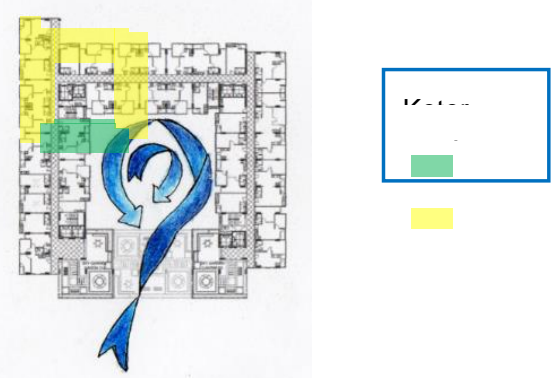

Figur 13. Ilustrasi Turbulensi pada Area Sky Garden Akibat Tower yang Berbentuk U

Suhu radiasi yang tinggi pada siang hari diakibatkan Area $\mathrm{G}$ dan $\mathrm{H}$ terkena radiasi matahari secara langsung, minim tanaman serta keberadaan pergola dengan material baja tidak memberikan pembayangan yang baik. Selisih suhu disebabkan tanaman pada Area $\mathrm{H}$ sangat minim sedangkan pada Area $G$ terdapat cukup banyak tanaman berupa perdu dalam 
pot yang memberikan pembayangan kurang luas, serta Area G menerima pembayangan oleh bentuk bangunan yang lebih baik yaitu selain pembayangan oleh tower 23 juga pembayangan oleh Area H diatasnya.

\section{b. Pilotis pada Lantai Dasar Massa Utama}

Apartemen Sudirman Suites merupakan bangunan tinggi dengan topografi sepenuhnya datar yang bagian dasarnya diangkat (pilotis) sehingga pencahayaan dan penghawaan alami dapat terjadi pada area dengan fungsi tempat parkir ini. Bagian dasar yang diangkat ini membentuk kolong di bagian bawah tower apartemen membuat percepatan angin yang tinggi pada lantai dasar karena angin dapat mengalir melalui kolong bangunan. Pada ground level pilotis terdapat 1 area ruang luar yaitu area parkir lantai dasar

- Area Parkir Lantai Dasar (Area A)

Tabel 5. Persepsi Kenyamanan Termal Area Parkir Lantai Dasar (Area A)

\begin{tabular}{|c|c|c|c|c|c|c|c|c|}
\hline \multirow{3}{*}{ Waktu } & \multirow{3}{*}{ TitikUkur } & \multicolumn{5}{|c|}{ Indikator } & \multirow{2}{*}{\multicolumn{2}{|c|}{ Hasil Perhitungan }} \\
\hline & & \multirow{2}{*}{$\begin{array}{l}\mathrm{RH} \\
(\%)\end{array}$} & \multirow{2}{*}{$\frac{\operatorname{tg}}{\left({ }^{\circ} \mathrm{C}\right)}$} & \multirow{2}{*}{$\begin{array}{c}\text { ta } \\
\left({ }^{\circ} \mathrm{C}\right)\end{array}$} & \multirow{2}{*}{$\begin{array}{c}\mathrm{AV} \\
(\mathrm{m} / \mathrm{s})\end{array}$} & \multirow{2}{*}{$\begin{array}{c}\text { Arah } \\
\text { Angin }\end{array}$} & & \\
\hline & & & & & & & Nilai & Persepsi \\
\hline \multirow{3}{*}{ Pagi } & A1 & 78.9 & 26.0 & 25.0 & 1.6 & $\mathrm{BD}$ & 0.043 & Nyaman \\
\hline & $\mathrm{A} 2$ & 79.0 & 26.1 & 25.2 & 1.2 & $\mathrm{TL}$ & 0.202 & Nyaman \\
\hline & A3 & 78.6 & 26.2 & 25.4 & 1.0 & TL & 0.294 & Nyaman \\
\hline \multirow{3}{*}{ Siang } & A1 & 69.8 & 28.1 & 27.5 & 4.9 & $\mathrm{BD}$ & -0.786 & Agak Dingin \\
\hline & $\mathrm{A} 2$ & 69.2 & 28.5 & 27.8 & 4.2 & $\mathrm{TL}$ & -0.484 & Nyaman \\
\hline & A3 & 69.2 & 28.5 & 27.9 & 3.8 & $\mathrm{TL}$ & -0.336 & Nyaman \\
\hline \multirow{3}{*}{ Sore } & A1 & 72.3 & 26.5 & 25.9 & 4.2 & $\mathrm{BD}$ & -0.751 & Agak Dingin \\
\hline & $\mathrm{A} 2$ & 72.6 & 26.1 & 25.6 & 3.5 & TL & -0.546 & Agak Dingin \\
\hline & A3 & 72.8 & 26.1 & 25.6 & 3.1 & TL & -0.404 & Nyaman \\
\hline
\end{tabular}

Berdasarkan data hasil pengukuran, Area A yang merupakan area parkir lantai dasar pada pagi hari menunjukkan persepsi nyaman sedangkan pada siang dan sore hari menunjukkan persepsi nyaman dan agak dingin. Hal tersebut terjadi akibat angin pada Area A cukup besar yakni pada pagi hari sebesar 1-2 m/s dan pada siang dan sore hari berkisar 3-5 m/s.

Perbedaan suhu udara antar fase waktu tidak terlalu kontas, yakni pada pagi hari sekitar $25^{\circ} \mathrm{C}$, siang hari sekitar $27-28^{\circ} \mathrm{C}$, dan sore hari $25-26^{\circ} \mathrm{C}$. Perbedaan kecepatan angin pada pagi hari berkisar 1-1.6 m/s cukup kontras dengan kecepatan angin pada siang dan sore hari yang cukup tinggi sekitar 3-5m/s dengan arah angin dominan titik A1 berasal dari arah barat daya, dan titik A2 dan A3 angin dominan berasal dari timur laut.

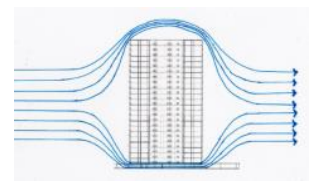

Figur 14. Ilustrasi Gerakan Udara pada Lantai Dasar Apartemen Akibat Bentuk Pilotis

Berdasarkan teori, angin bergerak kencang pada Area A diakibatkan lantai dasar yang diangkat (pilotis) mengakibatkan angin dapat bergerak pada ruang bawah bangunan yang 
diangkat, sehingga meningkatkan kecepatan angin pada lantai dasar namun mereduksi angin pada sisi windward bangunan apartemen secara keseluruhan.

Suhu radiasi pada Area A cenderung serupa antar setiap titiknya dalam setiap fase waktu. Suhu radiasi tertinggi terjadi pada siang hari, berbanding terbalik dengan kondisi kelembapan relatif yang terendah pada siang hari. Penggunaan material perkerasan semen dan paving block dengan albedo 5-20\% yang sedikit memantulkan dan lebih banyak menyerap panas. Tanaman kurang berperan pada Area A akibat tanaman yang digunakan rendah dan tidak berdaun lebat sebaiknya diganti dengan tanaman yang lebih tinggi dan berdaun lebat sehingga lebih efektif dalam mereduksi angin dan memberikan pembayangan.

\section{c. Adisi Massa Penunjang}

Massa penunjang merupakan adisi bentuk pada massa utama apartemen dengan inner court dengan variasi ketinggian. Adisi bentuk memanjang setinggi 2 lantai ini memiliki fungsi sebagai area komersial yang merupakan massa transisi antara jalan raya yang bersifat publik dengan massa bangunan tower dengan fungsi sebagai hunian yang bersifat privat. Pada adisi massa penunjang ini, terdapat 3 area ruang luar yang akan dibahas yaitu teras dan lorong lantai dasar (Area B), teras dan lorong lantai 1 (Area C), dan roof garden lantai 2 (Area F).

- Teras dan Jalur Sirkulasi/ Lorong Lantai Dasar (Area B)

Tabel 6. Persepsi Kenyamanan Termal Area Teras dan Lorong Lantai Dasar (Area B)

\begin{tabular}{|c|c|c|c|c|c|c|c|c|}
\hline \multirow{3}{*}{ Waktu } & \multirow{3}{*}{ TitikUkur } & \multicolumn{5}{|c|}{ Indikator } & \multirow{2}{*}{\multicolumn{2}{|c|}{ Hasil Perhitungan }} \\
\hline & & \multirow{2}{*}{$\begin{array}{l}\mathrm{RH} \\
(\%)\end{array}$} & \multirow{2}{*}{$\begin{array}{c}\operatorname{tg} \\
\left({ }^{\circ} \mathrm{C}\right)\end{array}$} & \multirow{2}{*}{$\begin{array}{c}\text { ta } \\
\left({ }^{\circ} \mathrm{C}\right)\end{array}$} & \multirow{2}{*}{$\begin{array}{c}\mathrm{AV} \\
(\mathrm{m} / \mathrm{s})\end{array}$} & \multirow{2}{*}{$\begin{array}{l}\text { Arah } \\
\text { Angin }\end{array}$} & & \\
\hline & & & & & & & Nilai & Persepsi \\
\hline \multirow{2}{*}{ Pagi } & $\mathrm{B} 1$ & 74.0 & 27.0 & 26.8 & 0.7 & $\mathrm{BD}$ & 0.568 & Agak Panas \\
\hline & $\mathrm{B} 2$ & 75.4 & 26.5 & 26.5 & 0.4 & $\mathrm{~S}$ & 0.610 & Agak Panas \\
\hline \multirow{2}{*}{ Siang } & B1 & 66.8 & 29.6 & 29.1 & 1.7 & $\mathrm{BD}$ & 0.580 & Agak Panas \\
\hline & $\mathrm{B} 2$ & 68.0 & 29.1 & 28.5 & 1.1 & $\mathrm{~S}$ & 0.720 & Agak Panas \\
\hline \multirow{2}{*}{ Sore } & B1 & 71.1 & 28.3 & 27.8 & 1.1 & $\mathrm{BD}$ & 0.597 & Agak Panas \\
\hline & $\mathrm{B} 2$ & 71.2 & 27.6 & 27.4 & 0.4 & $\mathrm{~S}$ & 0.776 & Agak Panas \\
\hline
\end{tabular}

Dari data hasil pengukuran di atas, hasil perhitungan pengukuran Area B yang merupakan lantai dasar adisi massa penunjang pada setiap fase waktu menunjukkan kondisi agak panas. Suhu dan kecepatan udara pada titik ukur B1 lebih tinggi diakibatkan letaknya yang berdekatan dengan jalan sehingga menerima pantulan panas lebih banyak dan lebih dekat dengan sumber angin dibandingkan titik B2 yang lebih dalam. Pada titik B1 angin berasal dari arah barat daya, dan titik B2 angin berasal dari selatan, hal ini diakibatkan oleh bentuk lorong ruang titik B2 yang terhimpit dinding area komersial dengan bangunan gereja di sebelahnya. Area B merupakan area semi terbuka yang terlindungi dari sinar radiasi matahari secara langsung.

- Teras dan Jalur Sirkulasi/ Lorong Lantai Dasar (Area C)

Tabel 7. Persepsi Kenyamanan Termal Area Teras dan Lorong Lantai 1 (Area C)

\begin{tabular}{|c|c|c|c|c|c|c|c|c|}
\hline \multirow{3}{*}{ Waktu } & \multirow{3}{*}{ TitikUkur } & \multicolumn{5}{|c|}{ Indikator } & \multirow{2}{*}{\multicolumn{2}{|c|}{ Hasil Perhitungan }} \\
\hline & & \multirow{2}{*}{$\begin{array}{l}\mathrm{RH} \\
(\%)\end{array}$} & \multirow{2}{*}{$\underset{\left({ }^{\circ} \mathrm{C}\right)}{\operatorname{tg}}$} & \multirow{2}{*}{$\begin{array}{c}\text { ta } \\
\left({ }^{\circ} \mathrm{C}\right)\end{array}$} & \multirow{2}{*}{$\begin{array}{c}\mathrm{AV} \\
(\mathrm{m} / \mathrm{s})\end{array}$} & \multirow{2}{*}{$\begin{array}{l}\text { Arah } \\
\text { Angin }\end{array}$} & & \\
\hline & & & & & & & Nilai & Persepsi \\
\hline \multirow{2}{*}{ Pagi } & $\mathrm{C} 1$ & 75.5 & 26.7 & 26.5 & 0.5 & $\mathrm{BD}$ & 0.589 & Agak Panas \\
\hline & $\mathrm{C} 2$ & 77.0 & 25.9 & 26.1 & 0.2 & $\mathrm{~S}$ & 0.602 & Agak Panas \\
\hline
\end{tabular}




\begin{tabular}{|c|c|c|c|c|c|c|c|c|}
\hline \multirow{2}{*}{ Siang } & $\mathrm{C} 1$ & 67.2 & 29.2 & 28.8 & 1.5 & $\mathrm{BD}$ & 0.604 & Agak Panas \\
\cline { 2 - 9 } & $\mathrm{C} 2$ & 67.6 & 29.2 & 28.6 & 1.3 & $\mathrm{~S}$ & 0.664 & Agak Panas \\
\hline \multirow{2}{*}{ Sore } & $\mathrm{C} 1$ & 69.6 & 27.5 & 27.3 & 0.8 & $\mathrm{BD}$ & 0.636 & Agak Panas \\
\cline { 2 - 9 } & $\mathrm{C} 2$ & 70.1 & 27.0 & 26.7 & 0.3 & $\mathrm{~S}$ & 0.747 & Agak Panas \\
\hline
\end{tabular}

Berdasarkan hasil perhitungan pengukuran Area $\mathrm{C}$ yang merupakan lantai 1 adisi massa penunjang pada setiap fase waktu menunjukkan kondisi agak panas. Suhu udara, suhu radiasi, dan kecepatan angin tertinggi terjadi pada siang hari sedangkan kelembapan tertinggi terjadi pada pagi hari. Suhu dan kecepatan udara pada titik ukur C1 lebih tinggi diakibatkan letaknya yang berdekatan dengan jalan sehingga menerima pantulan panas lebih banyak dan angin yang lebih kencang (lebih dekat dengan sumber angin) dibandingkan titik C2, hal tersebut juga turut terjadi pada Area B yang terletak di lantai dasar. Kondisi suhu dan kecepatan udara pada Area $\mathrm{C}$ cenderung berpola serupa baik dari segi arah ataupun kecepatan angin dengan Area B yang berada di lantai dasar. Efek venturi pada lorong tereduksi disebabkan lorong bersifat semi terbuka dengan celah pada bagian atap dan dindingnya sehingga kecepatan angin menurun dan terasa nyaman sebesar 0.2-1.5 m/s (skala Beaufort kecepatan 0.6-1.5 m/s memberi cooling effect).

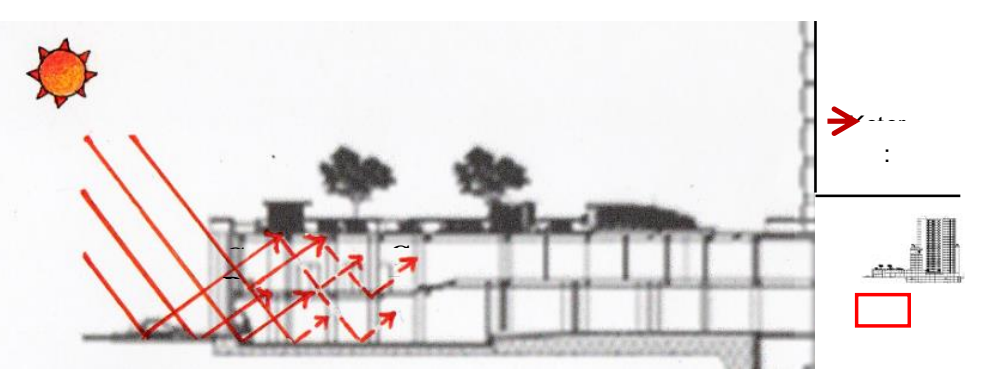

Figur 15. Ilustrasi Pantulan Radiasi pada Area B dan C

- Roof Garden Lantai 2 (Area F)

Tabel 4.8. Persepsi Kenyamanan Termal Area Roof Garden Lantai 2 (Area F)

\begin{tabular}{|c|c|c|c|c|c|c|c|c|}
\hline \multirow{3}{*}{ Waktu } & \multirow{3}{*}{ TitikUkur } & \multicolumn{5}{|c|}{ Indikator } & \multirow{2}{*}{\multicolumn{2}{|c|}{ Hasil Perhitungan }} \\
\hline & & \multirow{2}{*}{$\begin{array}{l}\text { RH } \\
(\%)\end{array}$} & \multirow{2}{*}{$\underset{\left({ }^{\circ} \mathrm{C}\right)}{\operatorname{tg}}$} & \multirow{2}{*}{$\begin{array}{c}\text { ta } \\
\left({ }^{\circ} \mathrm{C}\right)\end{array}$} & \multirow{2}{*}{$\begin{array}{c}\text { AV } \\
(\mathrm{m} / \mathrm{s})\end{array}$} & \multirow{2}{*}{$\begin{array}{l}\text { Arah } \\
\text { Angin }\end{array}$} & & \\
\hline & & & & & & & Nilai & Persepsi \\
\hline \multirow{4}{*}{ Pagi } & $\mathrm{F} 1$ & 67.6 & 29.1 & 27.1 & 0.4 & $\mathrm{BD}$ & 0.542 & Agak Panas \\
\hline & $\mathrm{F} 2$ & 65.8 & 29.7 & 27.4 & 0.2 & $\mathrm{BD}$ & 0.761 & Agak Panas \\
\hline & F3 & 69.7 & 27.9 & 26.6 & 0.7 & TG & 0.675 & Agak Panas \\
\hline & $\mathrm{F} 4$ & 70.6 & 27.5 & 26.2 & 0.4 & $\mathrm{BD}$ & 0.726 & Agak Panas \\
\hline \multirow{4}{*}{ Siang } & $\mathrm{F} 1$ & 62.4 & 32.0 & 30.6 & 3.4 & $\mathrm{BD}$ & -0.365 & Nyaman \\
\hline & $\mathrm{F} 2$ & 58.6 & 34.7 & 32.1 & 2.7 & $\mathrm{BD}$ & 0.522 & Agak Panas \\
\hline & F3 & 57.1 & 35.2 & 32.6 & 2.2 & $\mathrm{~B}$ & 1.085 & Agak Panas \\
\hline & $\mathrm{F} 4$ & 60.1 & 34.2 & 31.3 & 3.4 & $\mathrm{~B}$ & 0.491 & Nyaman \\
\hline \multirow{4}{*}{ Sore } & $\mathrm{F} 1$ & 70.2 & 27.0 & 26.7 & 1.9 & $\mathrm{BD}$ & -0.609 & Agak Dingin \\
\hline & $\mathrm{F} 2$ & 69.0 & 27.6 & 27.2 & 1.1 & $\mathrm{BD}$ & -0.068 & Nyaman \\
\hline & F3 & 69.3 & 27.6 & 26.9 & 1.4 & $\mathrm{~B}$ & 0.415 & Nyaman \\
\hline & $\mathrm{F} 4$ & 69.2 & 28.0 & 27.2 & 2.1 & $\mathrm{~B}$ & 0.208 & Nyaman \\
\hline
\end{tabular}

Hasil perhitungan pengukuran Area F yang merupakan lantai teratas adisi massa penunjang menunjukkan bahwa titik F1 lebih dingin dengan persepsi nyaman pada pagi hari dan agak dingin pada siang dan sore hari. Titik F2, F3, dan F4 menunjukkan persepsi agak panas pada pagi dan siang hari serta nyaman pada sore hari. Hal tersebut selain disebabkan perbedaan aktivitas yaitu duduk, juga kecepatan udara titik F1 lebih tinggi dibandingkan titik F2 dengan aktivitas yang sama. 
Suhu udara pada siang hari terlihat kontras lebih tinggi $\left(32-35^{\circ} \mathrm{C}\right)$ dibandingkan suhu udara pada pagi dan sore hari $\left(27-29^{\circ} \mathrm{C}\right)$ akibat area ini menerima radiasi langsung.

Pada adisi massa penunjang, perbedaan kecepatan angin pada siang hari sangat kontras antara Area F sebesar $3.4 \mathrm{~m} / \mathrm{s}$ dan $2.7 \mathrm{~m} / \mathrm{s}$ dengan Area B dan C sekitar 1.1-1.7 m/s, sedangkan perbedaan kecepatan angin pada sore hari tidak sebesar siang hari. Perbedaan tersebut terjadi akibat kecepatan angin yang semakin tinggi seiring bertambahnya ketinggian, selain itu, Area F yang terletak di atap bangunan dan hanya dibatasi oleh dinding $1 \mathrm{~m}$ disekelilingnya sehingga menerima lebih banyak angin dibandingkan Area B dan C yang lebih terbatas (dibatasi dinding). Semakin dekat titik ukur dengan sumber angin dominan, semakin besar kecepatan anginnya, hal tersebut terlihat pada data hasil pengukuran bahwa kecepatan angin titik B1, C1, dan F1 lebih besar dibandingkan titik B2, C2, dan F2.

Terdapat perbedaan suhu radiasi pada area massa adisi penunjang yaitu Area $\mathrm{F}$ dengan Area $\mathrm{B}$ dan $\mathrm{C}$ sangat kontras yaitu berselisih sekitar $3^{\circ} \mathrm{C}$ pada pagi dan siang hari, dengan selisih paling ekstrem titik $\mathrm{F} 2$ pada siang hari sebesar $5{ }^{\circ} \mathrm{C}$. Perbedaan suhu radiasi pada sore hari tidak berbeda jauh yaitu sekitar $1^{\circ} \mathrm{C}$ akibat cuaca yang semakin berawan. Perbedaan suhu yang ekstrem di titik F2 pada siang hari, diakibatkan selain Area F yang mendapatkan radiasi matahari langsung dibandingkan Area B dan C, juga titik F2 yang berada di tengah mendapatkan pantulan panas lebih besar dan kecepatan angin lebih rendah dibandingkan titik F1.

Ditinjau dari pengaruh bentuk dan ketinggian bangunan Apartemen Sudirman Suites Bandung terhadap kenyamanan termal ruang luar, bahwa persepsi rata-rata hasil pengukuran pagi, siang, dan sore hari menunjukkan 12 titik dari 20 titik yaitu pada area teras dan lorong lantai dasar dan lantai, sebagian area roof garden lantai 2, sky garden lantai 9 dan 11, serta area inner court menunjukkan persepsi agak panas. Kemudian 6 titik lainnya yaitu pada area lounge lantai 1 , sebagian area parkir lantai dasar dan roof garden lantai 2 menunjukkan persepsi nyaman, dan 1 titik pada area parkir lantai dasar menunjukkan persepsi agak dingin.
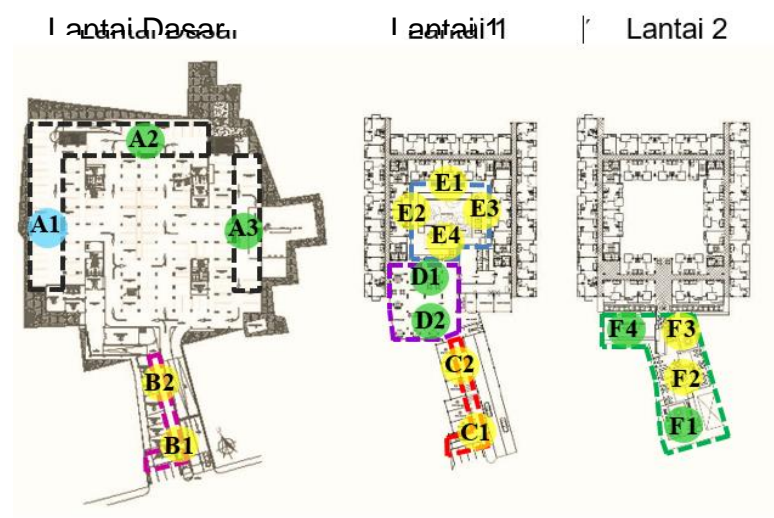

Lantai 9

Lantai 11
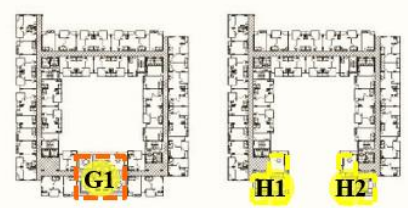

Figur 16. Kenyamanan Termal Ruang Luar pada Apartemen Sudirman Suites

Dari hasil penelitian, berikut ini fenomena yang ditemukan terkait pengaruh bentuk bangunan dengan inner court dan variasi ketinggian terhadap kenyamanan termal ruang luar Apartemen Sudirman Suites Bandung: (1) Perbandingan antara ketinggian - H tower penghalang (8 lantai) yang lebih rendah (berselisih 15 lantai) dengan jarak antar massa tower - W (lebar inner court) yang hampir sebanding sehingga nilai $\mathrm{H} / \mathrm{W}$ sekitar 1 membuat angin yang masuk ke area inner court berupa skimming flow dengan kecepatan 0.1-0.7 m/s yang tidak begitu efektif dalam mendinginkan suhu yang tinggi akibat radiasi matahari. (2) Bentuk apartemen dengan inner court memungkinkan aliran udara melewati ruang-ruang di sekitar inner court, seperti pada area lounge di lantai 1 yang persepsi kenyamanan termalnya nyaman. (3) Bentuk massa utama apartemen setinggi 23 lantai selain memberikan pembayangan pada tower itu sendiri, juga mampu memberikan pembayangan pada beberapa ruang luar di sekitar tower seperti area inner court di 
tengahnya, sebagian area roof garden dan sky garden, dan area parkir lantai dasar di luar bangunan (4) Lantai dasar pilotis mengakibatkan angin dapat bergerak pada ruang bawah apartemen yang diangkat, sehingga kecepatan angin pada area parkir lantai dasar di luar bangunan juga meningkat menjadi sekitar 3-5 m/s yang berdasarkan skala Beaufort pada manusia dirasakan rambut terganggu, baju ringan berkibar, ketidaknyamanan mulai terasa.(5) Bentuk lorong pada adisi massa penunjang mengarahkan angin namun efek venturi yang terjadi tereduksi akibat lorong bersifat semi terbuka dengan celah pada atap dan dinding pembatas apartemen dengan bangunan gereja di sebelahnya, sehingga sebagian angin keluar dari celah tersebut. (6) Pada area sky garden lantai 9 dan 11 kecepatan angin berkisar 1.6-2.1 m/s akibat pada ketinggian 30-35m, tidak ada bangunan sekitar yang menghalangi sehingga selisih 2 lantai tidak memberikan perbedaan kecepatan angin yang signifikan. (7) Area sky garden lantai 9 terbayangi oleh sky garden lantai 11, sehingga terjadi reduksi radiasi matahari yang mengenai area tersebut akibat bentuk massa yang memiliki variasi ketinggian.

\section{KESIMPULAN}

Dari hasil penelitian terdapat beberapa hal yang dapat ditambahkan agar kenyamanan termal ruang luar apartemen dapat lebih optimal, yaitu: (1) Bentuk apartemen dengan inner court sebaiknya memperhatikan perbandingan parameter $\mathrm{H}$ dan $\mathrm{W}$ yang disesuaikan dengan kondisi kecepatan gerakan udara setempat dan ruang di sekitarnya sebaiknya lebih terbuka, memaksimalkan pergerakan udara untuk melewati ruang-ruang tersebut, (2) Bentuk apartemen dengan variasi ketinggian sebaiknya memperhatikan arah dankecepatan gerakan udara pada tiap-tiap ketinggian, sehingga dapat diketahui batas ketinggian sebuah ruang luar dengan kecepatan angin yang nyaman. Selain itu perlu diperhatikan rancangan variasi ketinggian baik dari segi posisi dan tinggi yang efektif dalam memberikan pembayangan yang maksimal, (3) Bentuk apartemen dengan politis, sebaiknya memperhatikan arah dan kecepatan gerakan udara setempat, sehingga dapat diketahui dampak positif atau negatif yang terjadi akibat bentuk pilotis tersebut, (4) Pada rooftop apartemen yang menerima radiasi matahari secara langsung, sebaiknya diberikan pembayangan khususnya pada area dengan aktivitas yaitu dengan kanopi atau pergola dengan tanaman rambat, sehingga penghuni nyaman beraktivitas, (5) Memperhatikan penataan perkerasan berdasarkan albedo yang dimiliki oleh tiap jenis material pelingkupnya, seperti pada area rooftop sebagian material hardscape yang terbayangi dapat diganti dengan material softscape seperti rumput gajah atau rumput kawat yang umumnya digunakan sebagai tanaman ground cover area rooftop. Selain itu pada area inner court, penggunaan material dengan warna gelap yang akan menyerap panas (albedo rendah) pada area yang tidak terbayangi sebaiknya dihindari sebab dapat menghambat pelepasan panas pada area inner court.

Melalui penelitian ini diharapkan dapat menjadi sebuah masukan dalam meningkatkan kondisi kenyamanan termal ruang luar bangunan tinggi serta memberikan kontribusi bagi penelitian sejenis.

\section{DAFTAR PUSTAKA}

ASHRAE. 1989. "Handbook of Fundamental Chapter 8" Physiological Principles, Comfort, and Health. USA: ASHRAE.

BOOTH, Norman K. 1983. Basic Elements of Landscape Architectural Design. Illinois: Waveland Press.

BOUTET, Terry S. 1987. Controlling Air Movement. New York: R. R. Doneley \& Sons Company. DE Chiara, Joseph \& John Callender. 1987. Time Saver Standards For Building Types: 2nd edition. Singapura: McGraw-Hill Book.

LECHNER, Norbert. 1991. Heating, Cooling, Lighting, Design Methods for Architects. New York: 
Effect of Building Form with Inner Court and Height Variations on Thermal Comfort Outdoor Space in Sudirman Suites Apartment Bandung

John Wiley \& Sons.

MANGUNWIJAYA, Y.B. 1988. Pengantar Fisika Bangunan, Jakarta: Djambatan.

OKE, T.R. 1978. Boundary Layer Climates. New York: John Wiley and Sons.

PRABAWASARI, V. W. \& Suparman, A. 1999. Tata Ruang Luar 01. Jakarta: Penerbit Gunadarma.

SANGKERTADI. 2013. Kenyamanan Termis di Ruang Luar Beriklim Tropis Lembab.

Bandung: Alfabeta. 